International Journal of Instruction e-ISSN: 1308-1470 • www.e-iji.net

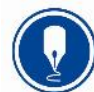

January $2022 \bullet$ Vol.15, No.1

p-ISSN: 1694-609X

pp. 619-632

Article submission code:

20210321035352

Received: 21/03/2021

Revision: 20/07/2021
Accepted: 14/08/2021

OnlineFirst: 08/11/2021

\title{
Exploring E-Learning Community of Inquiry Framework for Engineering Education
}

\section{Endina Putri Purwandari}

Faculty of Computer Science, Universitas Indonesia, Indonesia, ndina.putri91@ui.ac.id

\section{Kasiyah Junus}

Faculty of Computer Science, Universitas Indonesia, Indonesia, kasiyah@cs.ui.ac.id

\section{Harry Budi Santoso}

Faculty of Computer Science, Universitas Indonesia, Indonesia, harrybs@cs.ui.ac.id

This study aimed to investigate engineering students' learning experiences in eLearning Community of Inquiry (CoI) framework that integrates social, teaching, and cognitive presence to promote collaboration and critical thinking. Data analyzed quantitatively with descriptive statistics and multiple linear regression using IBM SPSS Statistics 26. The research location was at a state university in Bengkulu, Indonesia. Data were collected from 187 students consists of 112 men and 75 women. The questionnaire was derived from three elements of CoI. The results showed that (1) teaching presence has a higher contribution to cognitive presence than social presence for engineering education, (2) students were ready to construct the $\mathrm{CoI}$ in e-learning, and (3) students have positive feedback for the $\mathrm{CoI}$ evaluation in engineering education. Recommendations for engineering education include lecturers should be equipped with pedagogical competence and facilitate discussions using the CoI framework. Furthermore, students should contribute more actively to the social and cognitive presence.

Keywords: community of inquiry, e-learning, collaboration, cognitive presence, teaching presence

\section{INTRODUCTION}

The university's e-learning system is one way of producing the nation's generation with high-quality competitiveness with international standards. The Government of Indonesia issued a Freedom Education policy that maximizes a learning environment to achieve national education goals. Freedom to learn supported with Ministry of Education and Culture through regulations No 3 about National Standards of Higher Education, No 4 about Amendment to State Universities, No 5 about Accreditation for Study Program and University, No 6 about The Admissions of Undergraduate Programs, and No 7 about Establishment, Amendment, Dissolution of State Universities in 2020

Citation: Purwandari, E. P., Junus, K., \& Santoso, H. B. (2022). Exploring e-learning community of inquiry framework for engineering education. International Journal of Instruction, 15(1), 619-632. https://doi.org/10.29333/iji.2022.15135a 
(Kemendikbud, 2020). The CoI is very suitable to be applied for Freedom to Learn policy in Indonesia.

E-learning integrates not only online learning and direct interaction but also combines with collaborative inquiry in individual education. The $\mathrm{CoI}$ allows students to build knowledge by integrating students' potential and experiences in teaching, social, and cognitive presences. These three interdependent elements comprised essential ingredients to reach deep and meaningful learning outcomes (Bissessar et al., 2020). Therefore, the CoI was accepted as a framework to investigate students' experiences, learning processes, collaborative reflection, and problem-solving (Szeto, 2015).

There are some challenges in distance learning with no physical interaction, for both lecturers and students, with no face-to-face interaction between groupmates to perform group discussions. Students are expected to do independent learning, develop selfmotivated knowledge supplemented by internet literacy. Several platforms are used in online education, such as Google meet, Zoom meeting, and Cisco Webex. Students can use the meeting links and fill out the attendance list through a google form and Zoho form. Solimani et al. (2019) evaluated instruction with WhatsApp online conversation and $\mathrm{CoI}$ questionnaire to develop students' problem-solving ability. Another online discussion with mobile instant messaging integrated with e-Learning can support learning outcomes (Suana et al., 2019). Furthermore, e-Learning can support the cognitive presence through reflective writing and collaborative learning (Yaacob et al., 2021). Social presence pattern in postgraduate students positively correlates with academic performance (Al-dheleai \& Tasir, 2020).

Research objectives were: (1) to investigates e-Learning experience in engineering students; (2) to analyze the CoI framework in e-Learning to promote students collaboration. The analysis from this study as literature and recommendations in developing self-capacities and self-reflection on COI application in higher education. $\mathrm{CoI}$ can keep online education quality with a positive correlation between elements of social, teaching, and cognitive presences that can facilitate deep and meaningful educational experiences (Sağlam et al., 2020; Zhang, 2020).

\section{Community of Inquiry}

The CoI framework focused on online learning experiences from text-based, asynchronous, and online learning satisfaction. The CoI framework conceptualized in teaching, social, and cognitive presences to attain meaningful education through constructivist-oriented instruction (Figure 1). These three presences represent the educational experience in e-learning that has the same role in developing deeper learning quality as a cognitive process (Vaughan et al., 2019). The social and teaching process contributes as a catalysator of learning process. Social presence is student's ability to project themselves socially and emotionally through communication media. Cognitive presence is interpreted as students that construct knowledge through continuous communication (Akyol \& Garrison, 2011). 


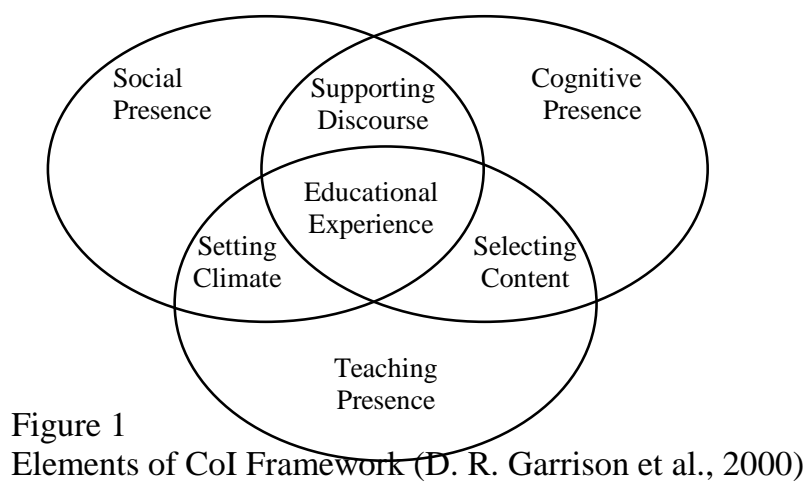

Several studies have been surveyed to understand the function and relationship between three elements of the CoI in online learning. The three presences have some differences demonstrated by the CoI survey and online collaboration analysis. Online courses' social presence increased the higher-level affective expression and group cohesion (M. Nasir, 2020). Teaching presence facilitates students through course facility interpreted as practical instruction in the learning process. This presence plays an essential role in promoting social presence for reciprocal communication and encouraging student achievement.

On the other hand, cognitive presence was the dominant part of social and teaching presence (Lim \& Richardson, 2021). Various experiments were conducted to adapt the CoI elements, such as cognitive outcomes and student satisfaction (Giannousi \& Kioumourtzoglou, 2016). The comparison between flipped and unplugged instructions using CoI indicated that both instructions could promote learners' problem solving (Solimani et al., 2019). The relationship between three aspects of CoI framework can enhance student proficiency and confidence, positively impacting students' confidence (Akyol et al., 2009). The impact of CoI indicated a positive correlation between social and cognitive presence (Sidiropoulou \& Mavroidis, 2019). Furthermore, mixed methods with validated the CoI reveal that students negatively perceive social presence and positive engagement in teaching and cognitive presence (Damm, 2016). Apart from differing views, the $\mathrm{CoI}$ is essential to initiate students in shaping educational experience knowledge.

Social presence is supported by open communication, group cohesion, and affective expression. It can minimize students' isolation feelings, reduce the differences between students and lecturers, improve academic ability, and contribute as a vital part of learning performance (Aldheleai et al., 2020). If the community established social presence, then cognitive presence facilitated learners to construct knowledge with sustainable reflection. Cognitive presence operationalized through four elements includes (a) triggering event to define and understand the problem; (b) exploration of the discussion issue and critical reflection; (c) integration to construct meaning from exploration idea; and (d) resolution that apply new knowledge into a real-world context (Yang \& Mohd, 2020). Three components of CoI have a mutual association with each 
other and a significant effect on learning outcomes. This study has drawn the students learning in an online course by utilizing the CoI to explore students' online learning experiences.

\section{METHOD}

This study describes metacognitive abilities through CoI framework for students in engineering faculty. This study adopts the questionnaires for online learning (Parkes et al., 2015), and metacognition conducts learning activities (D.R. Garrison \& Akyol, 2015). Then, these questionnaires were mapped according to the CoI framework by following elements, categories, and indicators (D.R. Garrison et al., 2010). The course was entirely online through asynchronous and synchronous platforms. Then, the results were analyzed quantitatively and described qualitatively.

A purposive sample data collection was carried out from April to May 2020 at one public university in Sumatra Island with university accreditation in grade B. This technique was chosen because sampling as a data source is by the considerations or criteria of phenomena, such as departments using e-Learning continuously and classes from various academic year levels. University with B accreditation has a good quality system, good quality of service, and a good information system. The research sample consisted of 187 student respondents spread across six different subject classes and different grades in the Spring semester. Respondent data distribution was secondsemester students $19 \%$, fourth-semester students $40 \%$, and sixth-semester students $41 \%$ (Table 1).

Table 1

Respondents distribution of online learning in engineering education

\begin{tabular}{llllll}
\hline Course & Department & Semester & Male & Female & Total \\
\hline English for engineering & Information System & 2 & 17 & 19 & 36 \\
\hline Geographic Information Systems & Informatics & 4 & 18 & 21 & 39 \\
\hline Research Methodology & Information System & 4 & 21 & 14 & 35 \\
\hline Geographic Information Systems & Information System & 6 & 18 & 7 & 25 \\
\hline Mobile Application Development & Information System & 6 & 18 & 7 & 25 \\
\hline Information Systems Audit & Informatics & 6 & 20 & 7 & 27 \\
\hline Total & & & 112 & 75 & 187 \\
\hline
\end{tabular}

The instrument is divided into 26 items for social presence, 21 items for cognitive presence, and 28 items for teaching presence. The 75 items of CoI used a five-point Likert scale from very prepared to unprepared. This question was posted on the online course. Then the results were processed using IBM SPSS Statistics 26. Descriptive statistics used to examine through the CoI framework and multiple regression analysis to explore the CoI relationship. The grouping questions were mapped from the CoI framework (Table 2). 
Table 2

Items survey of CoI elements

\begin{tabular}{|c|c|c|}
\hline Elements & Categories & Sample items \\
\hline \multirow[t]{3}{*}{$\begin{array}{l}\text { Social } \\
\text { Presence }\end{array}$} & $\begin{array}{l}\text { Open } \\
\text { communication }\end{array}$ & $\begin{array}{l}\text { Respond to other members with respect, apply interpersonal communication } \\
\text { skills, social interaction with other members, give an input/ answer, criticize, } \\
\text { understand others, participate, and interact in course discussion. }\end{array}$ \\
\hline & $\begin{array}{l}\text { Group } \\
\text { Cohesion }\end{array}$ & $\begin{array}{l}\text { Encourage other members to respond positively, share personal experiences } \\
\text { related to other members or related to the topic, collaborate with other } \\
\text { members, explain the opinion, ethics in learning community, consistent } \\
\text { communication, observe other members, listen and give positive feedback, } \\
\text { interacted with individuals, comfortable with other members }\end{array}$ \\
\hline & $\begin{array}{l}\text { Affective } \\
\text { Expression }\end{array}$ & $\begin{array}{l}\text { Be able to form impression with other members, respond to a contribution, } \\
\text { sense of belonging to the course, proposing a new idea, provide responses } \\
\text { clearly and unambiguous, share opinions and clarify the understanding }\end{array}$ \\
\hline \multirow[t]{4}{*}{$\begin{array}{l}\text { Cognitive } \\
\text { Presence }\end{array}$} & $\begin{array}{l}\text { Triggering } \\
\text { Event }\end{array}$ & $\begin{array}{l}\text { Course increase my curiosity, level of motivation, awareness with student } \\
\text { effort, and thinking }\end{array}$ \\
\hline & Exploration & $\begin{array}{l}\text { Explore with varied information sources, dig for information with } \\
\text { brainstorming, confirm the understanding with others, assess the difficulty of } \\
\text { an issue, understand the process of cognition and thinking, navigate the } \\
\text { learning material in large quantities, appreciate different perspectives and } \\
\text { learning needs. }\end{array}$ \\
\hline & Integration & $\begin{array}{l}\text { Link old knowledge with newly learned knowledge, combine new information, } \\
\text { construct solutions, distinguish relevant /irrelevant information, develop } \\
\text { responses from various ideas, understand learning activities and fundamental } \\
\text { concepts in class. }\end{array}$ \\
\hline & Resolution & $\begin{array}{l}\text { Evaluate the understanding, implemented relevant learning strategy, developed } \\
\text { a solution to course problem, evaluate my perspective on an issue, assess } \\
\text { learning results critically, evaluate the learning strategies }\end{array}$ \\
\hline \multirow{4}{*}{$\begin{array}{l}\text { Teaching } \\
\text { Presence }\end{array}$} & Design \& & Demonstrate knowledge and utilize the Learning Management System, present \\
\hline & Organization & $\begin{array}{l}\text { learning content in various formats, identify all requirements to complete the } \\
\text { task, upload and download information and learning resources, to construct } \\
\text { knowledge with course topics, course goals, and learning activities }\end{array}$ \\
\hline & $\begin{array}{l}\text { Facilitating } \\
\text { Discourse }\end{array}$ & $\begin{array}{l}\text { Identifying areas on course topics to learn, guiding the class, use search } \\
\text { engines effectively, use the web-browser skillfully, integrate various software } \\
\text { applications to create a product, use the freedom offered by the virtual learning } \\
\text { environment, access information from multiple sources, make an appropriate } \\
\text { strategic plan to complete the task, encourage students to explore new } \\
\text { concepts, access information from various sources, reinforced the development } \\
\text { of students }\end{array}$ \\
\hline & $\begin{array}{l}\text { Direct } \\
\text { Instruction }\end{array}$ & $\begin{array}{l}\text { Focus on the discussion in relevant issues, provide time in asynchronous } \\
\text { discussions, implement a problem-solving strategy, utilize feedback to evaluate } \\
\text { performance, identify gaps in understanding and correct them, evaluate } \\
\text { positively as a learner, appreciate and recognize the role of students in the } \\
\text { learning environment, providing feedback in a timely fashion }\end{array}$ \\
\hline
\end{tabular}

\section{FINDINGS}

The research instrument was distributed online through an e-learning portal. After the data was obtained, validity and reliability tests were performed. Validity testing aims to measure the accuracy of the instrument's questions that represent actual conditions (Mohajan, 2017). Reliability refers to the instrument's ability to provide optimal results. The average score of validity tests was above 0.7 , which means the instrument's questions were valid with improved language fluency and fluency. The reliability 
assessment results using Cronbach's alpha levels were higher than 0.9, which means all the instruments were reliable. The closer Cronbach's alpha coefficient is to 1 , the greater the internal consistency of items in a scale. Table 3 shows that all instruments have good validity and provide reliable data with the CoI framework. Table 4 showed the descriptive statistics for three elements of CoI. It can be seen that the highest rating for social presence $($ mean $=4.17)$, teaching presence $($ mean $=4.11)$, and cognitive presence (mean $=4.08)$. The scale range for this research is 5 points, so the mean interpretation is classified into three (3) categories, which are low (1.00-2.33), moderate (2.34-3.67), and high (3.68-5.00) (Kotschevar \& Withrow, 2012).

Table 3

Result of validity and reliability instrument

\begin{tabular}{lllll}
\hline Instrument & Validity $(\mathrm{R})$ & & \multicolumn{2}{l}{ Reliability (Cronbach's Alpha) } \\
\hline Social Presence & 0.74 & Valid & 0.96 & Reliable \\
\hline Cognitive Presence & 0.76 & Valid & 0.94 & Reliable \\
\hline Teaching Presence & 0.72 & Valid & 0.92 & Reliable \\
\hline
\end{tabular}

Table 4

Result of descriptive statistics for CoI elements

\begin{tabular}{llll}
\hline Elements & Mean & SD & N \\
\hline Social Presence & 4.17 & 0.73 & 26 \\
Open Communication & 4.26 & 0.61 & 5 \\
Group Cohesion & 4.15 & 0.79 & 14 \\
Affective Expression & 4.15 & 0.69 & 7 \\
\hline Cognitive Presence & 4.08 & 0.79 & 21 \\
Triggering Event & 4.21 & 0.77 & 3 \\
Exploration & 4.10 & 0.71 & 8 \\
Integration & 4.07 & 0.78 & 4 \\
Resolution & 4.00 & 0.92 & 6 \\
\hline Teaching Presence & 4.11 & 0.71 & 28 \\
Design \& Organization & 4.14 & 0.73 & 5 \\
Facilitating Discourse & 4.11 & 0.72 & 11 \\
Direct Instruction & 4.08 & 0.70 & 12 \\
\hline
\end{tabular}

Next, we analyzed with Multiple Linear Regression (MLR) to determine the statistical correlation between teaching, social, and cognitive presences. Table 5 presents the hypothesis Social Presence $\rightarrow$ Cognitive Presence is accepted, where social presence positively impacts cognitive presence to use e-learning at Sig $0.028<0.05(\beta=0.44)$. The results of $\mathrm{R}$ square $=0.242$, which $24.2 \%$ of social presence as a predictive variable contributed to the dependent variable in cognitive presence. Furthermore, Teaching Presence $\rightarrow$ Cognitive Presence is also accepted, where teaching presence has a significant influence on cognitive presence with Sig $0.023<0.05(\beta=0.458)$. The $\mathrm{R}$ square $=0.258$ showed that $25.8 \%$ of teaching presence was contributed to the cognitive presence in engineering education. To sum up, the Beta coefficients for teaching presence variables are slightly increased than social presence in cognitive presence. 
Table 5

Results of hypotheses testing

\begin{tabular}{lllllll}
\hline Hypotheses & $\begin{array}{l}\text { Coef. } \\
\text { Beta }\end{array}$ & $\begin{array}{l}\text { Pearson } \\
\text { Corr. }\end{array}$ & R Square & T-Values & Sig. & Support \\
\hline $\begin{array}{l}\text { Social Presence } \rightarrow \\
\text { Cognitive Presence }\end{array}$ & 0.440 & 0.552 & 0.242 & 2.41 & 0.028 & Yes \\
\hline $\begin{array}{l}\text { Teaching Presence } \rightarrow \\
\text { Cognitive Presence }\end{array}$ & 0.458 & 0.526 & 0.258 & 2.51 & 0.023 & Yes \\
\hline
\end{tabular}

Table 6 shows the multiple regression analysis results for two predictors variable (teaching and social presences) with $\mathrm{R}$ square $=0.501$, which these predictors contribute $50.1 \%$ to the dependent variable (cognitive presence). The collinearity tolerance and Variance Inflation Factor (VIF) examine the multicollinearity for these predictors. The collinearity tolerance is $0.941<1$, and the VIF value $1.062<1.0$ indicated that these predictors influence each other. Additionally, the Sig of Anova and F Change $0.004<$ 0.001 showed a meaningful correlation between the cognitive presence and teaching and social presence.

Table 6

Results of multiple regression analysis

\begin{tabular}{llllllll}
\hline $\begin{array}{l}\text { Dependent } \\
\text { Variable }\end{array}$ & $\begin{array}{l}\text { Predictors } \\
\text { Variable }\end{array}$ & $\begin{array}{l}\text { R } \\
\text { Square }\end{array}$ & $\begin{array}{l}\text { F } \\
\text { Change }\end{array}$ & $\begin{array}{l}\text { Sig. F } \\
\text { Change }\end{array}$ & $\begin{array}{l}\text { Anova } \\
\text { Sig. }\end{array}$ & Collinearity & VIF \\
\hline $\begin{array}{l}\text { Cognitive } \\
\text { Presence }\end{array}$ & $\begin{array}{c}\text { Teaching \& } \\
\text { Social Presences }\end{array}$ & 0.501 & 8.026 & 0.004 & 0.004 & 0.941 & 1.062 \\
\hline
\end{tabular}

Figure 2 shows the path analysis model for three elements of CoI. Teaching presence has a more significant contribution to cognitive presence than social presence. The results indicate that the student was ready and actively construct $\mathrm{CoI}$ in e-learning.

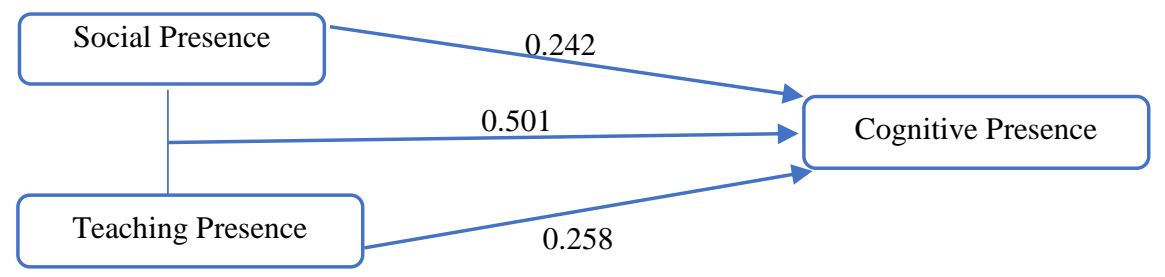

Figure 2

Path analysis model for CoI elements

\section{DISCUSSION}

E-Learning has many challenges in building cognitive, social, and teaching presences. Instruction in online learning can enhance the interaction between social and teaching presence (Stevens \& Rice, 2016). Some online learning strategies can support learners by redirecting dialogue, establishing a social presence, and problem-solving in collaboration. The interrelations between the CoI elements can help the driver to construct effective online learning. 
Based on Figure 2, social presence is lower than cognitive and teaching presence. This presence has multidimensional characteristics that need additional time to reach a higher perceived level (Lim \& Richardson, 2021). Teaching presence was the core of establishing a social and cognitive presence (D.R. Garrison et al., 2010). The relationship between social and teaching presence supports the hypothesis that this presence is essential to establish a cognitive presence. This finding, similar to a study conducted with Saglam reported that enriching cognitive presence may also encourage social and teaching presence levels (Saglam \& Dikilitas, 2020). This research contributes to determining the $\mathrm{CoI}$ elements that have a significant impact on learning objectives and meaningful learning outcomes.

Online learning not only involves uploading material and assignments but also building interaction in the learning class. Online learning uses the facilities of Learning Management System (LMS), Google Classroom, and Zoom Meeting. There are differences in implementing online and offline learning. Based on experiences and learning sessions at each meeting, students feel a social presence through online discussions. Emotional involvement can be built together between lecturers and students, improving social presence in the CoI (Sulisworo et al., 2020). In the end, of course, students were provided individually with anonymous feedback as a course evaluation from students (Subheesh \& Sethy, 2020). Students' feedback shows there are positive attitudes towards online learning and discussion. This feedback can be seen from the following comments.

(1) "Lebih mudah dilakukan di mana saja dan kapan saja, lebih fleksibel dalam mengatur jadwal, dan lebih hemat pengeluaran." (Easier to learn anywhere and anytime, more flexible in arranging schedules, and more cost-effective)

(2) "Diskusi online bisa direcord, jadi saya bisa kapan saja ingin menontonnya kembali." (Online discussions can be recorded, so I can always watch them again at any time)

(3) "Diskusi online yang dilakukan dapat mengembangkan karakter mandiri mahasiswa dengan mencari informasi menggunakan teknologi yang tersedia, tidak hanya terpaku akan pengetahuan yang diberikan pengajar." (Online discussions can develop students' independence by finding information using available technology, not only focusing on the knowledge provided by the lecturer)

(4) "Dapat menghindari untuk tidak berkumpul dalam masa pandemi, stay di rumah dan menjaga kesehatan." (Online learning is beneficial for the pandemic as it can prevent people from gathering, can encourage them to stay at home and maintain their health)

(5) "Keinginan saya belajar tanpa harus tatap muka terkabul, karena saya sangat merasa seperti mahasiswa di kelas internasional di luar negeri, menggali dan melakukan journey terhadap diri sendiri untuk memperoleh pengetahuan." (My wish to study without having face-to-face instruction has come true, because I really feel like a student in an international class abroad, exploring and traveling on my own journey to gain knowledge)

(6) "Metode diskusi online sangat membantu hubungan dosen dan mahasiswa sangat komunikatif, bisa dibilang seperti private learning." (Having online discussions 
establishes good communication between the lecturers and students and feels like private learning)

(7) "Tidak terlalu formal, menyampaikan pendapat tanpa rasa canggung, melihat bagaimana tanggapan anggota lain terhadap suatu masalah, membuat kita merasa nyaman dalam kegiatan berdiskusi." (Expressing opinions without feeling awkward, not too formal, seeing how other members respond to a problem, make us feel comfortable in discussions)

(8) "Menambah pengetahuan lebih tidak terlalu gugup saat diskusi dapat mencari informasi lebih, karena saya orangnya pemalu jika berpendapat secara face to face, ketika belajar online saya lebih terbuka untuk berdiskusi." (Increases my knowledge as I'm less nervous during discussions and can seek more information, because I am a shy person when I have to give opinions face to face, when studying online I am more open to discussion)

From the comments above, it could be concluded that the students feel comfortable with online learning and discussion. It shows that social presence aspects have emerged from functional interactions between learners in online classes. They have the same expectations, and mutual trust builds up among them as learners. Furthermore, the interaction in social presence patterns contributes to students' academic performance (Al-dheleai \& Tasir, 2020).

Furthermore, the learners have a positive attitude to interaction in the online classroom, which is seen in the following comment: a sense of comfort during interaction with fellow learners, feel comfortable participating in discussions, chatting, and asking questions during learning (Junus et al., 2019). Learning interactions in social presence such as having enough time to learn, getting feedback, ability to disagree, having the openness of opinion, getting assistance in learning from other learners, match the material to scientific needs, and encouraging of all learning desires have a positive response from learners (D. R. Garrison et al., 2010). Next, the social aspect of attendance is seen through interpersonal relations between students and four different communication media types: audio, video, telephone through Moodle e-Learning, and Zoom Meeting applications. All this allows verbal communication and non-verbal communication expressed through visuals and symbols and personal relationships and interactions that carry socio-emotional information in academic terms (D. Randy Garrison \& Arbaugh, 2007).

Generally, students complain about unstable internet network signals and the power of bandwidth that affect the quality of online discussions and video calls. Not all students have the same internet and electricity signal quality standards resulting in slow system response. Internet and electricity network connection support is a technical supporting factor for the implementation of e-Learning. However, a few students below $3 \%$ think online learning is not as beneficial as offline learning. They should become accustomed to online learning methods and discuss assignments online. High control from the teacher can improve cognitive presence but decreases social presence in the discussion forum. 
There were several significant obstacles, such as understanding learning material that was not taught face-to-face. Students tended to be passive, so that online discussions became challenging to understand because of group members' inability to participate. The desire for learning decreased because there were no physical friends to share motivation. The faster discussion flow can cause the students to need more time to understand the discussion contents. It caused some students to lose concentration when following the discussion.

Online learning gives some advantages in the teaching and learning activities for higher education. However, the implementation of e-Learning still needs a lot of adaptation, both lecturers and students, to find the most effective learning strategies (Mailizar et al., 2020). The students' learning materials and the willingness to participate in online learning are essential to successful online learning implementation (Sulisworo et al., 2020). An online education that engages both the students and instructors can increase student metacognitive ability (Junus et al., 2019).

There are recommendations in e-Learning implementation (1) the university as a learning institution should introduce strategic plans to develop courses with critical learning and thinking skills; (2) lecturers should provide the CoI frameworks in managing online discussions that are more meaningful and sustainable; and (3) students should contribute more actively in e-Learning to deepen their understanding in the form of social and cognitive presence (Kasiyah, 2019). The CoI framework provides sequences and guidelines for exploring blended learning designs by presenting learning processes and outcomes that are formed coherently and accurately (Junus et al., 2019). Students that actively in social presence have better academic performance (Aldheleai et al., 2020). Furthermore, all lecturers should be equipped with digital and pedagogical competence (Langford \& Damşa, 2020). Lecturers can arrange learning materials with diversified teaching plans, including different activities and materials to fulfill students' needs (Dulfer et al., 2017).

Based on experiments, information technology in e-learning can help prepare learning strategies, develop self-capacities, self-reflection, evaluation, study, learning quality, and broaden insights and experiences (Sugandi \& Kurniawan, 2018). The university also needs to increase its institutional capacity and policy to ensure reliable digital infrastructure, accessible resources, and cloud learning (Ruangvanich \& Piriyasurawong, 2019). Universities and their management should prepare particular policies and standard operating procedures for online and blended learning. Further research, the university needs to form a peer review team. They evaluate whether the teaching and learning process follows the pedagogical principles in online learning to improve the quality of online education. Pedagogical content knowledge can help the teacher deliver course material effectively and efficiently (Alimuddin et al., 2020). The university and lecturers must reinforce the learning process with a high-quality assessment.

\section{CONCLUSION}

This study showed the e-Learning for engineering education through CoI framework. Teaching presence has a higher contribution to cognitive presence than social presence 
in e-learning for engineering education. Most students gave positive feedback to eLearning activities for reasons such as learning material can be accessed anytime and anywhere, having the flexibility to choose learning topics and discussions, and costeffective.

Some improvement for e-Learning can be made by (1) providing students material about learning management system and time management to study at home for selfdevelopment; (2) training students to present reports for their learning assignments in various formats; (3) facilitating students to collaborate with their lecturers and group members in the learning process; (4) designing learning activities using small-sized files will significantly boost the learning process, especially for students with weak internet network signals. There is a challenge to enhance the collaborative learning community capability and support the CoI for engineering education.

Based on the study, we suggest that lecturers are equipped with digital and pedagogical competence, trained to develop learning material with diversified teaching plans and manage online discussions with the CoI frameworks. Students should contribute more actively to social and cognitive presence. As an educational institution, the university should form a peer review team to evaluate the teaching process and increase institutional capacity and policy.

\section{ACKNOWLEDGMENT}

This work is funded by the Research Grant International Publication PUTI Q2 2020 with the research topic Modelling Student Behavior and Educational Experience in Online Collaborative Learning, No. NKB-1480/UN2.RST/HKP.05.00/2020 from DRPM Universitas Indonesia.

\section{REFERENCES}

Akyol, Z., \& Garrison, D. R. (2011). Understanding cognitive presence in an online and blended community of inquiry: Assessing outcomes and processes for deep approaches to learning. British Journal of Educational Technology, 42(2), 233-250. https://doi.org/10.1111/j.1467-8535.2009.01029.x

Akyol, Z., Garrison, D. R., \& Ozden, M. Y. (2009). Development of a community of inquiry in online and blended learning contexts. Procedia - Social and Behavioral Sciences, 1(1), 1834-1838. https://doi.org/10.1016/j.sbspro.2009.01.324

Al-dheleai, Y. M., \& Tasir, Z. (2020). Online social presence "OSP" patterns correlation with students' academic performance among master of education program students. International Journal of Instruction, 13(2), 493-506. https://doi.org/10.29333/iji.2020.13234a

Aldheleai, Y. M., Tasir, Z., Al-Rahmi, W. M., Al-Sharafi, M. A., \& Mydin, A. (2020). Modeling of students online social presence on social networking sites with academic performance. International Journal of Emerging Technologies in Learning, 15(12), 5671. https://doi.org/10.3991/ijet.v15i12.12599 
Alimuddin, Z., Tjakraatmadja, J. H., \& Ghazali, A. (2020). Developing an instrument to measure pedagogical content knowledge using an action learning method. International Journal of Instruction, 13(1), 425-444. https://doi.org/10.29333/iji.2020.13128a

Bissessar, C., Black, D., \& Boolaky, M. (2020). International online graduate students' perceptions of CoI. European Journal of Open, Distance and E-Learning, 23(1), 61-83. https://doi.org/10.2478/eurodl-2020-0005

Damm, C. A. V. (2016). Applying a community of inquiry instrument to measure student engagement in large online courses. Current Issues in Emerging ELearning, $3(1)$,

$138-171$.

https://scholarworks.umb.edu/cieeAvailableat:https://scholarworks.umb.edu/ciee/vol3/is s1/9\%0Ahttp://scholarworks.umb.edu/ciee/vol3/iss1/9

Dulfer, N., Mckernan, A., \& Brindle, K. (2017). Different Countries, Different Approaches to Teaching and Learning? The University of Melbourne.

Garrison, D. R., Anderson, T., \& Archer, W. (2000). Critical inquiry in a text-based environment. The Internet and Higher Education, 2(2), 87-105. http://dergipark.gov.tr/saufenbilder/issue/20673/220600

Garrison, D. R., Anderson, T., \& Archer, W. (2010). The first decade of the community of inquiry framework: A retrospective. Internet and Higher Education, 13(1-2), 5-9. https://doi.org/10.1016/j.iheduc.2009.10.003

Garrison, D. Randy, \& Arbaugh, J. B. (2007). Researching the community of inquiry framework: Review, issues, and future directions. The Internet and Higher Education, 10(3), 157-172. https://doi.org/10.1016/j.iheduc.2007.04.001

Garrison, D.R., \& Akyol, Z. (2015). Toward the development of a metacognition construct for communities of inquiry. The Internet and Higher Education, 24, 66-71. https://doi.org/10.1016/j.iheduc.2014.10.001

Garrison, D.R., Cleveland-Innes, M., \& Fung, T. S. (2010). Exploring causal relationships among teaching, cognitive and social presence: Student perceptions of the community of inquiry framework. The Internet and Higher Education, 13(1-2), 31-36. https://doi.org/10.1016/j.iheduc.2009.10.002

Giannousi, M., \& Kioumourtzoglou, E. (2016). Cognitive, social, and teaching presence as predictors of students' satisfaction in distance learning. Mediterranean Journal of Social Sciences, 7(2), 439-447. https://doi.org/10.5901/mjss.2016.v7n2s1p439

Junus, K., Suhartanto, H., R-Suradujono, B. S. H., Santoso, H. B., \& Sadita, L. (2019). The community of inquiry model training using the cognitive apprenticeship approach to improve students' learning strategy in the asynchronous discussion forum. The Journal of Educators Online, 16(1). https://doi.org/10.9743/jeo.2019.16.1.7

Kasiyah. (2019). Pembelajaran kolaboratif daring asinkronus. UI Publishing.

Kemendikbud. (2020). Pedoman pelaksanaan belajar dari rumah selama darurat bencana covid-19 di Indonesia. Kemendikbud. 
Kotschevar, L. H., \& Withrow, D. (2012). Management by Menu (4th editio). Wiley.

Langford, M., \& Damşa, C. (2020). Online teaching in the time of Covid-19: Academic teachers experiences in Norway. Center of Experiental Legal Learning (CELL), University of Oslo, 2(April), 1-35. https://www.jus.uio.no/cell/

Lim, J., \& Richardson, J. C. (2021). Predictive effects of undergraduate students' perceptions of social, cognitive, and teaching presence on affective learning outcomes according to disciplines. Computers and Education, 161(November 2020), 104063. https://doi.org/10.1016/j.compedu.2020.104063

M. Nasir, M. K. (2020). The influence of social presence on students' satisfaction toward online course. Open Praxis, 12(4), 485. https://doi.org/10.5944/openpraxis.12.4.1141

Mailizar, M., Almanthari, A., Maulina, S., \& Bruce, S. (2020). Secondary school mathematics teachers' views on e-learning implementation barriers during the COVID19 pandemic: The case of Indonesia. Eurasia Journal of Mathematics, Science and Technology Education, 16(7), em1860. https://doi.org/10.29333/ejmste/8240

Mohajan, H. K. (2017). Two Criteria for Good Measurements in Research: Validity and Reliability. Annals of Spiru Haret University. Economic Series, 17(4), 59-82. https://doi.org/10.26458/1746

Parkes, M., Stein, S., \& Reading, C. (2015). Student preparedness for university elearning environments. Internet and Higher Education, 25, 1-10. https://doi.org/10.1016/j.iheduc.2014.10.002

Ruangvanich, S., \& Piriyasurawong, P. (2019). Structural equation model of acceptance cloud learning for sustainability usage in higher education institutes. International Journal of Emerging Technologies in Learning (IJET), 14(10), 18. https://doi.org/10.3991/ijet.v14i10.10045

Saglam, A. L. G., \& Dikilitas, K. (2020). Evaluating an Online Professional Learning Community as a Context for Professional Development in Classroom-based. The Electronic Journal for English as a Second Language, 24(3).

Sağlam, A. L. G., Dikilitaş, K., \& Zhang, R. (2020). Evaluating an online professional learning community as a context for professional development in classroom-based research. Language Learning and Technology, 24(3), 38-53. https://doi.org/10.125/44707

Sidiropoulou, Z., \& Mavroidis, I. (2019). The relation between the three dimensions of the community of inquiry and the learning styles of students in a distance education programme. International Journal of Emerging Technologies in Learning (IJET), 14(23), 180. https://doi.org/10.3991/ijet.v14i23.11564

Solimani, E., Ameri-Golestan, A., \& Lotfi, A. (2019). Flipped vs . unplugged instructions: Sailing EFL learners ' oral proficiency through virtual and real learning communities. International Journal of Instruction, 12(3), 459-480. 
https://doi.org/10.29333/iji.2019.12328a

Stevens, M., \& Rice, M. F. (2016). Inquiring into presence as support for student learning in a blended learning classroom. Journal of Online Learning Research, 2(4), 447-473. https://www-learntechlib-org.library.capella.edu/p/172449/

Suana, W., Distrik, I. W., Herlina, K., Maharta, N., \& Putri, N. M. A. A. (2019). Supporting blended learning using mobile instant messaging application: Its effectiveness and limitations. International Journal of Instruction, 12(1), 1011-1024. https://doi.org/10.29333/iji.2019.12165a

Subheesh, N. P., \& Sethy, S. S. (2020). Learning through assessment and feedback Practices: A critical review of engineering education settings. EURASIA Journal of Mathematics, Science and Technology Education, 16(3), 1-18. https://doi.org/10.29333/ejmste/114157

Sugandi, L., \& Kurniawan, Y. (2018). The influence of information technology on the information and service quality for the teaching and learning. International Journal of Emerging Technologies in Learning, 13(12), 230-237. https://doi.org/10.3991/ijet.v13i12.8665

Sulisworo, D., Rohmadheny, P. S., Fatimah, N., \& Arif, D. B. (2020). Learning analytics to predict student achievement in online learning during Covid- 19 mitigation. International Journal of Psychosocial Rehabilitation, 24(10), 1844-1861. https://doi.org/10.37200/IJPR/V24I10/PR300210

Szeto, E. (2015). Community of inquiry as an instructional approach: What effects of teaching, social and cognitive presences are there in blended synchronous learning and teaching? Computers \& Education, 81, 191-201. https://doi.org/10.1016/j.compedu.2014.10.015

Vaughan, N., Cleveland-Innes, M., \& Garrison, R. (2019). The community of inquiry framework: Future directions - shared metacognition. World COnference on Online Learning. https://wcol2019.ie/wp-content/uploads/presentations/FP_039, VAUGHAN.pdf

Yaacob, A., Asraf, R. M., Hussain, R. M. R., \& Ismail, S. N. (2021). Empowering learners' reflective thinking through collaborative reflective learning. International Journal of Instruction, 14(1), 709-726. https://doi.org/10.29333/iji.2021.14143a

Yang, L., \& Mohd, R. B. S. (2020). The relationship between critical thinking and the community of inquiry model: a quantitative study among EFL university students in China. International Journal of Adolescence and Youth, 25(1), 965-973. https://doi.org/10.1080/02673843.2020.1814359

Zhang, R. (2020). Exploring blended learning experiences through the community of inquiry framework. Language Learning and Technology, 24(1), 38-53. https://doi.org/10.125/44707 